\title{
ARTICLE Mimicking Cdk2 phosphorylation of Bcl-xL at Ser73 results in caspase activation and $\mathrm{Bcl}-\mathrm{xL}$ cleavage
}

\author{
NS Seng ${ }^{1}$, J Megyesi ${ }^{1,2}$, A Tarcsafalvi $^{2}$ and PM Price ${ }^{1,2,3}$
}

Cisplatin is a widely used chemotherapeutic agent, yet its efficacy is limited by nephrotoxicity. The severity of nephrotoxicity is associated with the extent of kidney cell death. Previously, we found that cisplatin-induced kidney cell death was dependent on Cdk2 activation, and inhibition of Cdk2 protected cells from cisplatin-induced apoptosis. Using an in vitro kination assay, we showed that $\mathrm{Cdk} 2$ phosphorylated $\mathrm{Bcl}-\mathrm{xL}$, an anti-apoptotic member of $\mathrm{Bcl}-2$ family proteins, at serine 73 . We also found that this phosphorylated $\mathrm{Bcl}-\mathrm{xL}$ participated in cell death, as a phosphomimetic mutant of $\mathrm{Bcl}-\mathrm{xL}$ at the serine 73 site (S73D-Bcl-xL) activated caspases. We now find that S73D-Bcl-xL was cleaved at D61 and D76, which are putative caspase cleavage sites, to generate 15-kDa and 12-kDa fragments. Unlike full-length $\mathrm{BCl}-\mathrm{xL}$, these cleavage products of $\mathrm{BCl}-\mathrm{xL}$ were previously reported to be pro-apoptotic. We sought to determine whether these Bcl-xL fragments were necessary for the induction of cell death by S73D-Bcl-xL. Mutation of these caspase cleavage sites prevented the formation of the 15-kDa and 12-kDa Bcl-xL cleavage products, but apoptosis still persisted in a S73D modified Bcl-xL. Our findings show that Cdk2 phosphorylation of $\mathrm{Bcl}-\mathrm{xL}$ at Ser73, but not the Bcl-xL cleavage products, is necessary and sufficient to induce cell death.

Cell Death Discovery (2016) 2, 16001; doi:10.1038/cddiscovery.2016.1; published online 1 February 2016

\section{INTRODUCTION}

Cis-diamminedichloroplatinum (II) or cisplatin has been widely used to treat various solid tumors, such as ovarian, testicular, head and neck, lung, and bladder cancers. ${ }^{1}$ In addition to causing cancer cell death, cisplatin also induces kidney cell death, and this nephrotoxicity is a major dose limiting factor of cisplatin in chemotherapy. ${ }^{2}$ Understanding the molecular mechanisms of cisplatin nephrotoxicity is important to find therapy to protect kidneys without compromising its anti-neoplastic effect.

Cyclin-dependent kinase $2(\mathrm{Cdk} 2)$ is primarily known as a cellcycle regulatory protein that participates in cell proliferation. Apart from its role in cell-cycle regulation, its role in cell death pathways is poorly understood but has become increasingly recognized. ${ }^{3-7}$ Our laboratory found that cisplatin-induced kidney cell death was dependent on Cdk2 activation, and inhibition of Cdk2 by p21, dominant-negative (DN)-Cdk2, or chemical inhibitors such as roscovitine or purvalanol protected kidney cells from cisplatininduced apoptosis both in vitro and in vivo. ${ }^{8-10}$ However, the mechanisms of how Cdk2 mediates apoptosis are still unknown. Using an analog-sensitive Cdk2 kinase (F80G-Cdk2), we found that after cisplatin treatment, $\mathrm{Cdk} 2$ phosphorylated $\mathrm{BCl}-\mathrm{xL}$, a cell survival protein, at a previously unreported Ser73 site. ${ }^{11}$

Although wild-type $\mathrm{BCl}-\mathrm{xL}$ (WT-BCl-xL) inhibits pore formation induced by active Bax/Bak, ${ }^{12-14}$ a phosphomimetic Bcl-xL in which Ser73 was replaced by Asp promoted mitochondrial permeabilization, caspase activation, and apoptosis. ${ }^{11}$ WT-Bcl-xL was reported to be cleaved after Asp61 and Asp76 (D61 and D76) by caspases. $^{15,16}$ The role of $\mathrm{BCl}-\mathrm{xL}$ cleavage in apoptosis is not well understood. It is unclear whether Bcl-xL cleavage results in loss of anti-apoptotic function, ${ }^{16}$ or whether the cleavage products could actively participate in apoptosis. ${ }^{15,17,18}$
In the present study, we report that Cdk2 phosphorylation of $\mathrm{BCl}-\mathrm{xL}$ at Ser73 is an upstream event resulting in perinuclear mitochondrial clustering, caspase activation, and subsequent $\mathrm{BCl}-\mathrm{xL}$ cleavage after D61 and D76. Furthermore, we show that Ser73 phosphorylation of $\mathrm{BCl}-\mathrm{xL}$, but not $\mathrm{BCl}-\mathrm{xL}$ cleavage is necessary and sufficient to trigger apoptosis.

\section{RESULTS}

Expression of phosphomimetic Bcl-xL at Ser73 resulted in $15 \mathrm{kDa}$ and $12 \mathrm{kDa}$ cleavage products from caspase activity

Using western blot analysis, we determined the expression of $\mathrm{BCl}-\mathrm{xL}$ before and after transduction (Figure 1a). In comparison with the level of endogenous full-length $\mathrm{BCl}-\mathrm{xL}$ in untransduced cells (Figure 1a, lane 1), transduction resulted in a several fold increase in full-length $\mathrm{Bcl}-\mathrm{xL}$ level (Figure 1a, lanes 2-5). In addition to full-length $\mathrm{Bcl}-\mathrm{xL}$, we also detected $15 \mathrm{kDa}$ and $12 \mathrm{kDa} \mathrm{BCl}-\mathrm{xL}$ cleavage products in S73D-Bcl-xL-expressing cells (Figure 1a, lane 4), but not in WT-BCl-xL-expressing cells (Figure 1a, lanes 2 and 3). Pretreatment of cells with $5 \mu \mathrm{M}$ pan-caspase inhibitor, zVAD-fmk, did not have any detectable effect on WT-BCl-xL-expressing cells (Figure 1a, lane 3 ), but it eliminated the cleavage products of $\mathrm{BCl}-x \mathrm{~L}$ from cells expressing S73D-BCl-xL (Figure 1a, lane 5), suggesting the involvement of active caspase(s) in the formation of $\mathrm{Bcl}-\mathrm{xL}$ cleavage products. The Cdk2 phosphorylation site (Ser73) and the reported caspase cleavage sites (D61 and D76) are indicated in the ribbon diagram of $\mathrm{Bcl}-\mathrm{xL}$, adapted from Muchmore et al. ${ }^{19}$ (Figure $1 \mathrm{~b}$ ).

${ }^{1}$ Department of Physiology and Biophysics, University of Arkansas for Medical Sciences, Little Rock, AR, USA; ${ }^{2}$ Division of Nephrology, Department of Internal Medicine, University of Arkansas for Medical Sciences, Little Rock, AR, USA and ${ }^{3}$ Central Arkansas Veterans Healthcare System, Little Rock, AR, USA. 


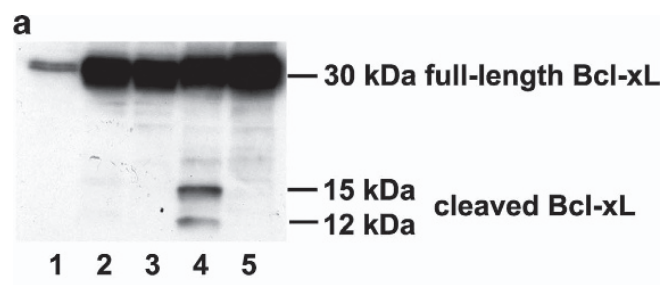

b

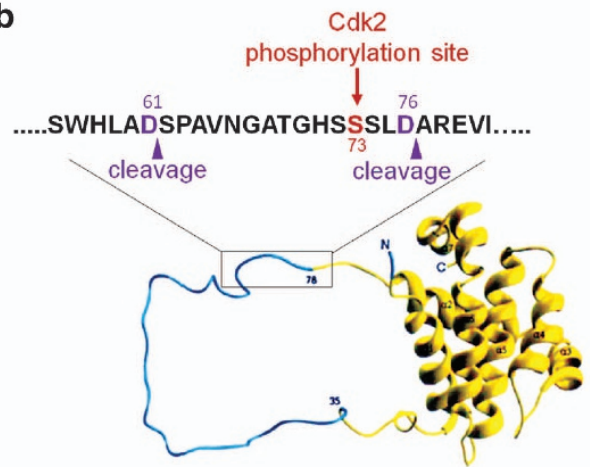

Figure 1. Phosphomimetic $\mathrm{BCl}-\mathrm{xL}(\mathrm{S} 73 \mathrm{D}-\mathrm{BCl}-\mathrm{xL})$ resulted in $15-\mathrm{kDa}$ and $12-\mathrm{kDa}$ cleavage products, which were eliminated by pancaspase inhibitor, zVAD-fmk. (a) Cellular proteins were processed from untreated, untransduced TKPTS cells (lane 1), TKPTS cells transduced for $72 \mathrm{~h}$ with WT-Bcl-xL (lane 2), with WT-Bcl-xL in the presence of $5 \mu \mathrm{M}$ zVAD-fmk (lane 3), with S73D-Bcl-xL (lane 4), and with S73D-Bcl-xL in the presence of $5 \mu \mathrm{M}$ zVAD-fmk (lane 5). Western blot analysis was performed to analyze for full-length $\mathrm{Bcl}-\mathrm{xL}$ (30 kDa) and $\mathrm{Bcl}-\mathrm{xL}$ cleavage products ( 15 and $12 \mathrm{kDa}$ ). (b) Ribbon diagram of $\mathrm{BCl}-\mathrm{xL}$ showing the unstructured loop domain (cyan) and the boxed region within this domain indicate the approximate positions where Cdk2 phosphorylation of Bcl-xL (Ser73) and caspase cleavage of $\mathrm{BCl}-\mathrm{xL}$ (D61 and D76) occur.

Endogenous $\mathrm{BCl}-\mathrm{xL}$ was cleaved in response to cisplatin exposure As S73D-BCl-xL mimics the phosphorylation of Bcl-xL by Cdk2 after cisplatin treatment, we investigated whether endogenous $\mathrm{BCl}-\mathrm{xL}$ would also be cleaved after cisplatin treatment. The cleavage of endogenous $\mathrm{BCl}-\mathrm{xL}$ was analyzed in the supernatant and membrane fractions of control untreated TKPTS cells and cisplatintreated TKPTS cells (Figure 2). No cleavage products of Bcl-xL were observed in the control and cisplatin-treated supernatant fractions (Figure 2, lanes 1 and 2), but both 15-kDa and 12-kDa cleavage products were localized in the membrane fraction of cisplatintreated TKPTS cells (Figure 2, lane 4). The cleavage products of $\mathrm{Bcl}-\mathrm{xL}$ were absent in the membrane fraction of the control untreated cells (Figure 2, lane 3).

Cleavage of endogenous $\mathrm{BCl}-\mathrm{xL}$ is dependent on active caspases downstream of Cdk2 activation

As the S73D-Bcl-xL cleavage products were eliminated by the pancaspase inhibitor, zVAD-fmk (Figure 1a, lane 5), we hypothesized that the cleavage of endogenous $\mathrm{BCl}-\mathrm{xL}$ observed after cisplatin exposure would similarly be prevented by zVAD-fmk. The cleavage of $\mathrm{BCl}-\mathrm{xL}$ was not observed in the membrane fraction of the untreated control cells (Figure 3a, lane 1), but it was detected in that of cisplatin-treated TKPTS cells (Figure 3a, lane 2). The cleavage products of $\mathrm{BCl}-\mathrm{xL}$ generated in response to cisplatin treatment were prevented by pretreating cells with pan-caspase inhibitor, zVAD-fmk (Figure 3a, lane 3). In addition, the cleavage products were also eliminated by inhibition of $\mathrm{Cdk} 2$ either by DN-Cdk2 transduction (Figure 3a, lane 5) or by pretreatment of cells with purvalanol (Figure 3a, lane 7). In the absence of cisplatin, TKPTS cells either transduced with DN-Cdk2 (Figure 3a, lane 4) or pretreated with purvalanol (Figure 3a, lane 6) had no effect on
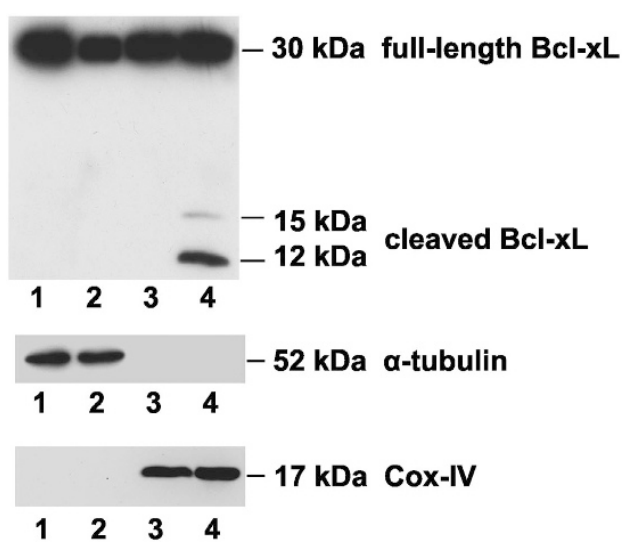

Figure 2. Cisplatin induced cleavage of Bcl-xL. TKPTS cells were either untreated (lanes 1 and 3) or treated with $25 \mu \mathrm{M}$ cisplatin for $24 \mathrm{~h}$ (lanes 2 and 4). Untreated control and cisplatin-treated TKPTS cells were processed into supernatant (lanes 1 and 2) and membrane fractions (lanes 3 and 4) as described in Materials and Methods. Western blot analysis was performed to detect full-length $\mathrm{Bcl}-\mathrm{xL}(30 \mathrm{kDa})$ and cleaved $\mathrm{Bcl}-\mathrm{xL}(15$ and $12 \mathrm{kDa})$. Alpha-tubulin and cytochrome c oxidase subunit IV (COX-IV) were used as markers to show the purity of the fractionations of supernatant and membrane containing mitochondria.

the cleavage of endogenous $\mathrm{Bcl}-\mathrm{xL}$. Caspase 3 was activated in TKPTS cells in the presence of cisplatin (Figure 3b, lane 2). Pretreatment of cells with either zVAD-fmk (Figure 3b, lane 3) or inhibition of Cdk2 either by overexpression of DN-Cdk2 (Figure 3b, lane 5) or by pretreatment of cells with purvalanol (Figure 3b, lane 7) prevented cisplatin-induced caspase 3 activation. DN-Cdk2 overexpression was observed where TKTPS cells were transduced with DN-Cdk2 adenovirus (Figure 3c, lanes 4 and 5). Compared with control untransduced cells (Figure $3 d$, lane a), TKPTS cells transduced with DN-Cdk2 or pretreated with purvalanol (Figure $3 d$, lanes $b$ and $c$, respectively) resulted in the inhibition of endogenous Cdk2 activity, as indicated by a reduction in the phosphorylation of histone $\mathrm{H} 1$, a known Cdk2 substrate.

Cleavage-resistant phosphomimetic Bcl-xL at Ser73 preserved its ability to induce apoptosis

WT-BCl-xL was reported to be cleaved by caspases after D61 and D76. ${ }^{15,16}$ To test whether S73D-Bcl-xL was cleaved at these residues, site-directed mutagenesis was performed to convert aspartic acids at 61 and 76 into alanines (that is, D61A and D76A), resulting in a triple mutated protein (D61A, S73D, and D76A) referred to hereafter as ADA-BCl-xL. Caspase 3 activation was detected in S73D-BCl-xLand ADA-BCl-xL-transduced cells (Figure 4a, lanes 3 and 4, respectively), but not in the untransduced control cells and cells transduced with WT-BCl-xL (Figure 4a, lanes 1 and 2, respectively). Caspase activation is the cause of $\mathrm{Bcl}-\mathrm{xL}$ cleavage (Figure 1a, lane 5 and $3 a$, lane 3). ${ }^{15,16,20} \mathrm{Bcl}-x \mathrm{~L}$ cleavage was not detected in control untransduced cells and cells transduced with WT-Bcl-xL (Figure 4b, lanes 1 and 2, respectively) since caspase was not activated under those conditions (Figure 4a, lanes 1 and 2). The caspase activation resulted in $15-\mathrm{kDa}$ and $12-\mathrm{kDa}$ cleavage products in S73D-Bcl-xL transduced cells (Figure 4b, lane 3). Although caspase activity was detected in ADA-BCl-xL-expressing cells (Figure $4 a$, lane 4), Bcl-xL cleavage products were not generated (Figure 4b, lane 4), suggesting that the cleavage sites were conserved at D61 and D76 in S73D-Bcl-xL, and substituting alanine residues on those sites abolished $\mathrm{BCl}-\mathrm{xL}$ cleavage. Control untransduced cells and WT-BCl-xL transduced cells were morphologically similar, as represented by solid monolayers of healthy cells (Figure 4c, 1 and 2, respectively). Similar to S73D-BCl-xL, ADA-BCl-xL was able to induce apoptosis, which was evident by morphological changes such as cell shrinkage, 
a

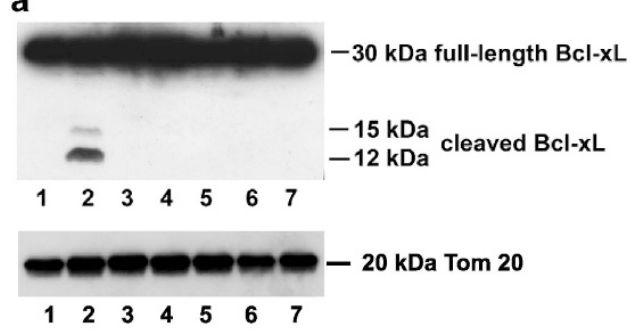

c

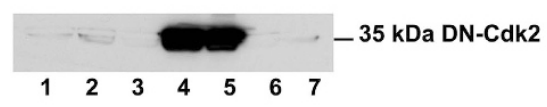

b

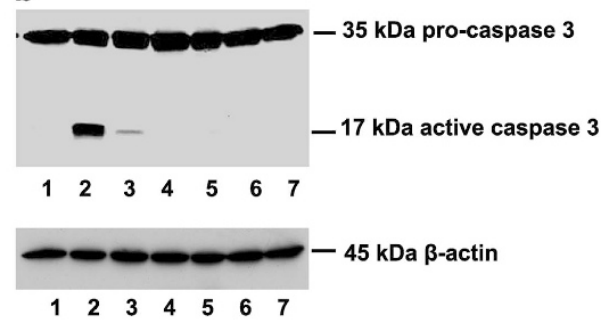

d

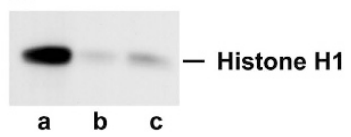

Figure 3. Endogenous $\mathrm{BCl}-\mathrm{xL}$ cleavage was associated with caspase 3 activation, and was downstream of Cdk2 activation. TKPTS cells were untreated and untransduced (lane 1) and treated with $25 \mu \mathrm{M}$ cisplatin for $24 \mathrm{~h}$ (lanes 2, 3, 5, and 7). To inhibit Cdk2 activity, TKPTS cells were transduced with $100 \mathrm{MOI}$ DN-Cdk2 $24 \mathrm{~h}$ before cisplatin exposure (lanes 4 and 5) or treated with $9 \mu \mathrm{M}$ purvalanol $1 \mathrm{~h}$ before cisplatin exposure (lanes 6 and 7). To inhibit caspase activity, $5 \mu \mathrm{M}$ zVAD fmk was added $1 \mathrm{~h}$ before cisplatin exposure (lane 3). After $24 \mathrm{~h}$ of cisplatin treatment, cells were processed into (a) mitochondria/membrane fraction for western blot analysis of Bcl-xL and Tom20 (loading control), (b) supernatant fraction for western blot analysis of caspase 3 and $\beta$-actin (loading control) and (c) DN-Cdk2. (d) Histone kinase assay was performed on untransduced TKPTS cells (lane a), TKPTS cells treated with purvalanol (lane b), and TKPTS cells transduced with DN-Cdk2 (lane c).

a

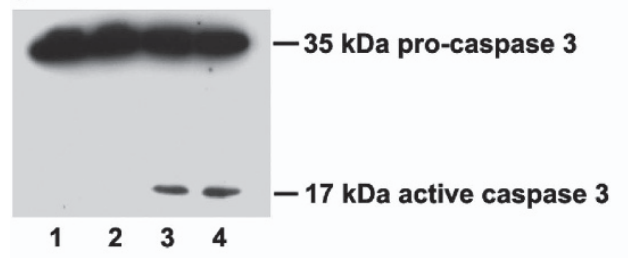

C
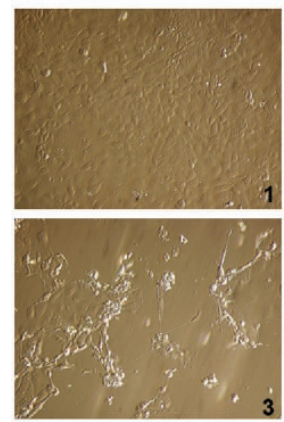
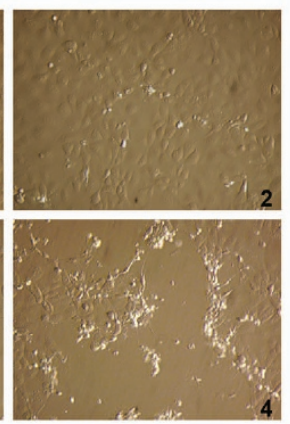

b

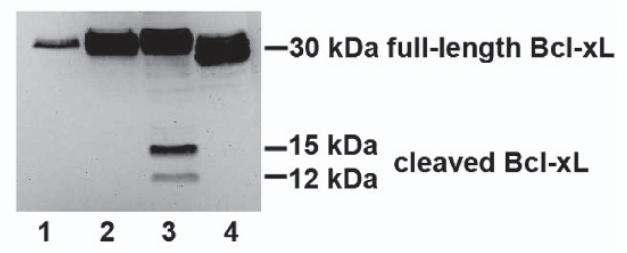

d

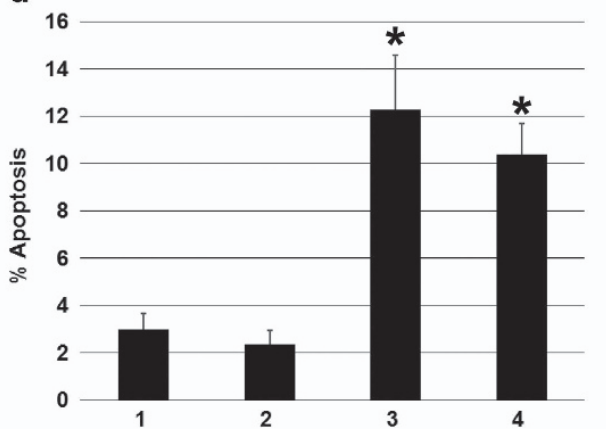

Figure 4. Caspase-resistant $\mathrm{BCl}-\mathrm{xL}$ (ADA-Bcl-xL) preserved its ability to induce apoptosis despite the lack of Bcl-xL cleavage products. TKPTS cells were untransduced (1), transduced for $72 \mathrm{~h}$ with WT-Bcl-xL (2), with S73D-Bcl-xL (3) and with ADA-Bcl-xL (4). Western blot analysis was performed to detect (a) pro-caspase 3 and active caspase 3 and (b) Bcl-xL and its cleavage products. (c) Cellular morphology of TKPTS cells was documented with Hoffmann Modulation Contrast microscope, $\times 20$ objective. (d) The percentage of apoptosis (Sub G0/G1 region of cell-cycle analysis) was also quantified by using propidium iodide and flow cytometry. Data are represented by the mean \pm S.E.M. of at least three independent experiments. Statistical significance was calculated using two-tailed Student's $t$-test, with asterisk $\left(^{*}\right)$ representing $P<0.05$.

membrane blebbing, and cell detachment (Figure 4c, 3 and 4, respectively). The percent of apoptosis in cells expressing ADA-Bcl-xL (10.40 $\pm 0.61 \%$, Figure $4 d$, bar 4) was significantly higher than the percent of apoptosis in control untransduced cells $(2.98 \pm 0.66 \%$, Figure $4 \mathrm{~d}$, bar 1$)$ and cells expressing WT-Bcl-xL $(2.35 \pm 0.60 \%$, Figure $4 d$, bar 2$)$, but not significantly different from the percent of apoptosis in cells expressing S73D-Bcl-xL $(12.27 \pm 2.32 \%$, Figure $4 d$, bar 3$)$.

ADA-BCl-xL and S73D-BCl-xL induce perinuclear clustering of mitochondria

Mitochondrial morphology and subcellular distribution change during apoptosis; mitochondria are dispersed throughout the cytoplasm in normal cells, but are condensed and clustered in perinuclear regions in apoptotic cells. ${ }^{21}$ Using fluorescent microscopy, we determined the subcellular distribution of mitochondria in cells expressing WT-Bcl-xL, S73D-Bcl-xL, and ADA-Bcl-xL, using 4',6-diamidino-2-phenylindole (DAPI) and Mitotracker Red CMXRos to mark nuclei and mitochondria, respectively. Cells expressing transduced $\mathrm{Bcl}-\mathrm{xL}$ were identified by GFP fluorescence, as GFP was co-expressed in the adenoviral expression vectors. Mitochondria were dispersed throughout the cytoplasm in WT-Bcl-xL-expressing cells similar to untransduced cells (cells without GFP marker), but were clustered in the perinuclear region in S73D-BCl-xL- and ADA-BCl-xL-expressing cells (Figure 5), consistent with their localization in the early stages of apoptosis. 

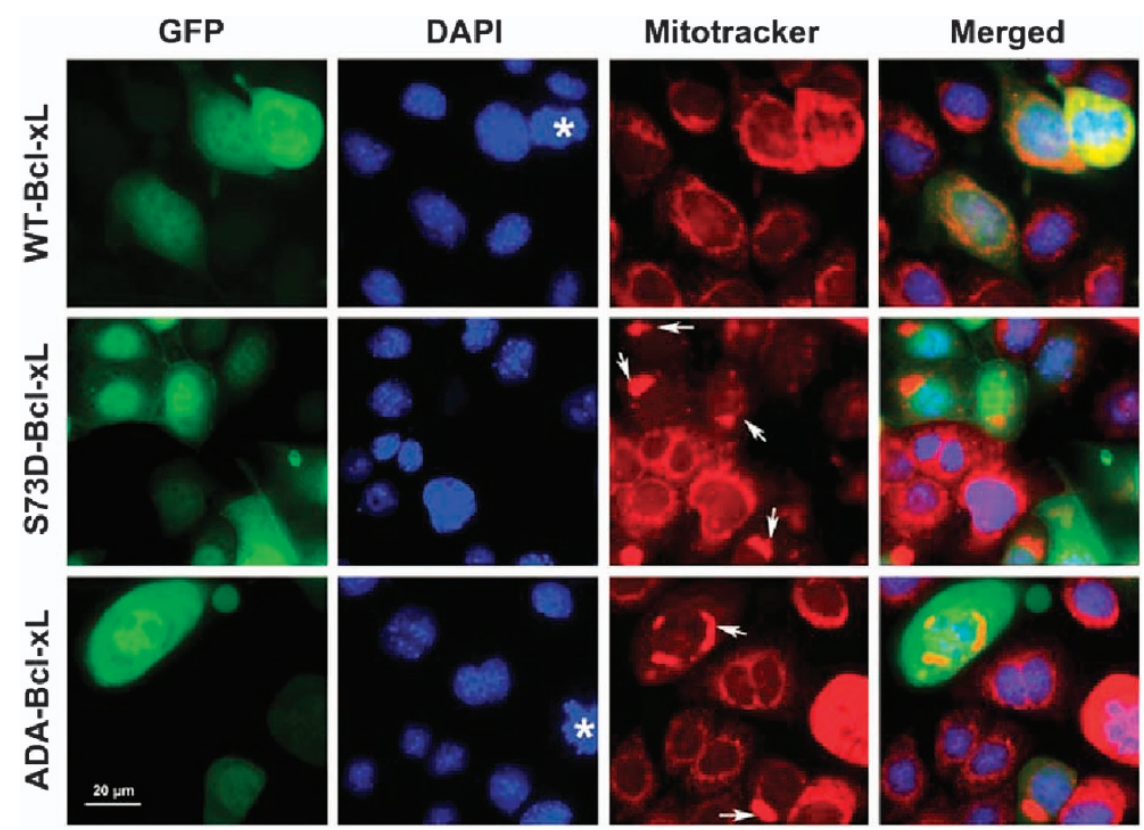

Figure 5. Expression of $A D A-B c l-x L$ and $S 73 D-B c l-x L$ resulted in perinuclear mitochondrial clustering. TKPTS cells transduced with $W T-B c l-x L$, S73D-Bcl-xL, and ADA-Bcl-xL for $48 \mathrm{~h}$ were photographed using a Nikon Eclipse Ti-S fluorescent microscope. GFP expressing cells identified cells transduced with $\mathrm{BCl}-\mathrm{xL}$. DAPI and Mitotracker Red CMXRos were used to stain nuclei and mitochondria, respectively. Asterisks represent dividing cells, which alters the intensity of GFP. White arrows indicate mitochondrial clustering. Merged pictures showed the perinuclear localization of clustered mitochondria in S73D-Bcl-xL- and ADA-Bcl-xL-expressing cells.

\section{DISCUSSION}

$\mathrm{BCl}-\mathrm{xL}$ contains an unstructured loop domain (amino acids, 26-83), which is a regulatory region of $\mathrm{BCl}^{-\mathrm{xL}}{ }^{22}$ known to be modulated by phosphorylation ${ }^{23,24}$ and cleavage. ${ }^{15,16}$ Recently, we reported that in normal kidney cells, Bcl-xL was phosphorylated at Ser73 within the unstructured loop domain in response to cisplatin exposure. ${ }^{11}$ Ser73 phosphorylation converted Bcl-xL into a potent pro-apoptotic pore forming molecule, which oligomerized at the mitochondria to release cytochrome $\mathrm{c}$ and activate caspase $3 .{ }^{11}$ In addition, Ser73 phosphorylation promoted the cleavage of $\mathrm{Bcl}-\mathrm{xL}$, as evident by the formation of the 15-kDa and 12-kDa fragments specifically in cells expressing phosphomimetic S73D-Bcl-xL (Figure 1a, lane 4 and Figure $4 \mathrm{~b}$, lane 3 ), but not the wild-type $\mathrm{Bcl}-\mathrm{xL}$ (Figure 1a, lane 2 and Figure 4b, lane 2). These cleavage products were resulted from upstream caspase activation as pretreatment of cells with zVAD-fmk prevented $\mathrm{Bcl}-\mathrm{xL}$ cleavage (Figure 1a, lane 5).

In response to cisplatin exposure, endogenous $\mathrm{Bcl}-\mathrm{xL}$ was cleaved into fragments similar to $\mathrm{S} 73 \mathrm{D}-\mathrm{BCl}-\mathrm{xL}$ fragments, suggesting that $\mathrm{BCl}-\mathrm{xL}$ cleavage is a relevant biological process in cisplatin-induced apoptosis. However, unlike the S73D-Bcl-xLexpressing cells (Figure 1a, lane 4 and Figure $4 b$, lane 3 ), cells exposed to cisplatin generated the $12-\mathrm{kDa}$ cleavage product in higher quantity than the 15-kDa cleavage product (Figure 2, lane 4 and Figure $3 a$, lane 2). Such differences could be explained by the fact that $\mathrm{S} 73 \mathrm{D}-\mathrm{BCl}-\mathrm{xL}$ induced cell death represents only a subset of the many cell death pathways induced by cisplatin. It is possible that proteases that process $\mathrm{Bcl}-\mathrm{xL}$ into the $12-\mathrm{kDa}$ cleavage product were more activated in cisplatin-treated cells than in S73D-Bcl-xL-expressing cells.

As pan-caspase inhibitor, zVAD-fmk, prevented the endogenous cleavage of $\mathrm{BCl}-\mathrm{xL}$ (Figure $3 \mathrm{a}$, lane 3 ), the cleavage of $\mathrm{Bcl}-\mathrm{xL}$ is downstream of caspase activation. Cdk2 activation is upstream of caspase activation because inhibition of Cdk2 either by DN-Cdk2 (Figures $3 a$ and b, lane 5) or by purvalanol (Figures $3 a$ and b, lane 7) prevented caspase activation (caspase 3 ) and subsequent $\mathrm{Bcl}-\mathrm{xL}$ cleavage. Expression of phosphomimetic S73D-Bcl-xL resulted in caspase activation, ${ }^{11}$ suggesting that Cdk2 phosphorylation of $\mathrm{BCl}-\mathrm{xL}$ at Ser73 is upstream of caspase activation, but downstream of Cdk2 activation.

The 15-kDa cleavage product of $\mathrm{Bcl}-\mathrm{xL}$ has a similar molecular weight as $\mathrm{BCl}-\mathrm{xS}$, a proapoptotic isoform of $\mathrm{BCl}-\mathrm{xL}$, and we investigated whether the observed cleavage product could be $\mathrm{Bcl}-\mathrm{xS}$. BCl-xS is produced from $\mathrm{Bcl}-x$ gene with $\mathrm{BH} 1$ and $\mathrm{BH} 2$ domains truncated due to alternative splicing of $B c l-x$ mRNA. ${ }^{25}$ On the other hand, $\mathrm{BCl}-\mathrm{xL}$ cleavage products are produced post-translationally by activated caspases, resulting in the loss of the $\mathrm{BH} 4$ domain. ${ }^{15,16}$ Since the formation of both the $15-\mathrm{kDa}$ and $12-\mathrm{kDa} \mathrm{Bcl}-\mathrm{xL}$ fragments could be prevented by zVAD-fmk, we concluded that those fragments were $\mathrm{Bcl}-\mathrm{xL}$ cleavage products rather than $\mathrm{BCl}-\mathrm{xS}$.

$\mathrm{BCl}-\mathrm{xL}$ was previously reported to be cleaved after D61 and D76 by caspases. ${ }^{15,16}$ Mutating these cleavage sites on S73D-Bcl-xL, that is, D61A, S73D, D76A-Bcl-xL (ADA-Bcl-xL) eliminated the $15-\mathrm{kDa}$ and $12-\mathrm{kDa}$ fragments (Figure $4 \mathrm{~b}$, lane 4). Despite the absence of $\mathrm{BCl}-\mathrm{xL}$ cleavage products, $\mathrm{ADA}-\mathrm{BCl}-\mathrm{xL}$ was still able to induce caspase 3 activation (Figure $4 a$, lane 4) and apoptosis (Figure 4c, panel 4 and Figure 4d, bar 4), indicating that phosphorylation of $\mathrm{BCl}-\mathrm{xL}$ at Ser73 rather than its cleavage was necessary and sufficient to induce apoptosis.

Mitochondria are normally distributed throughout the entire cytoplasm. ${ }^{21}$ Perinuclear mitochondrial clustering has been reported in apoptotic cells induced by various stimuli such as TRAIL, ${ }^{26}$ exogenous expression of $\mathrm{t}^{-B_{i d}}{ }^{27}$ and $\mathrm{Bax}^{21}$ aluminum maltolate, ${ }^{28}$ and staurosporin. ${ }^{28}$ Although perinuclear mitochondrial clustering is a phenotype consistently associated with apoptosis, it is still not clear whether mitochondrial clustering facilitates cell death. It is speculated that condensation of mitochondria could mediate the release of apoptogenic factors from mitochondria, and perinuclear localization hastens the delivery of pro-apoptotic molecules from the mitochondria into the nucleus, thereby increasing the rate of apoptosis induction. ${ }^{21}$ Here, we show that $A D A-B c l-x L$ induces perinuclear clustering of mitochondria, similar to S73D-BCl-xL (Figure 5). This suggests that $\mathrm{Cdk} 2$ phosphorylation of $\mathrm{BCl}-\mathrm{xL}$ was sufficient to cause 
mitochondrial redistribution and caspase activation, independent of $\mathrm{BCl}-\mathrm{xL}$ cleavage.

Our data suggest that $\mathrm{Cdk} 2$ phosphorylation of $\mathrm{Bcl}-\mathrm{xL}$ at Ser73 is an important part of cisplatin-induced kidney cell death pathways (Figure 6). Caspases, activated by phosphomimetic S73D-Bcl-xL, proteolyzed $\mathrm{Bcl}-\mathrm{xL}$ into the $15-\mathrm{kDa}$ and $12-\mathrm{kDa}$ cleavage products. Elimination of the caspase cleavage sites resulted in the absence of the $\mathrm{BCl}-\mathrm{xL}$ cleavage products, but did not prevent mitochondrial redistribution, caspase activation, and subsequent apoptosis, indicating that the cleavage products were not essential for apoptosis induction. However, the differences in the intensities of the $\mathrm{Bcl}-\mathrm{xL}$ cleavage products between cisplatin-induced apoptosis and S73D-BCl-xL-induced apoptosis suggest that the mechanisms of how the cleavage products are generated could be regulated by more than one pathway. It is known that cisplatin triggers multiple cell death pathways, ${ }^{2,29}$ and $\mathrm{Cdk} 2$ phosphorylation of $\mathrm{BCl}-\mathrm{xL}$ represents one of these modes. Further investigations on how the cleavage products are generated, especially in cisplatin-treated cells, could offer insights into mechanisms of cisplatin-induced cell death.

\section{MATERIALS AND METHODS}

Cell culture

Mouse kidney proximal tubule cells (TKPTS) ${ }^{30}$ were grown in DMEM+Ham's F-12 culture medium supplemented with $50 \mu \mathrm{U} / \mathrm{ml}$ insulin and 7\% FBS at $37^{\circ} \mathrm{C}$ in $5 \% \mathrm{CO}_{2}$. At $75 \%$ confluency of cells, cisplatin (APP Pharmaceuticals, Schaumburg, IL, USA) was added, where indicated, to a final concentration of $25 \mu \mathrm{M}$. Purvalanol A (540500, Calbiochem, San Diego, CA, USA) and zVAD-fmk (627610, Calbiochem, San Diego, CA, USA) were added $1 \mathrm{~h}$ before cisplatin treatment to 9 and $5 \mu \mathrm{M}$, respectively, where indicated. Adenovirus expressing wild-type $\mathrm{BCl}-\mathrm{xL}$, phosphomimetic $\mathrm{BCl}-\mathrm{xL}$ (S73D-BCl-xL), and cleavage-resistant phosphomimetic Bcl-xL (D61A, S73D, D76A-Bcl-xL) were added, where indicated, at a final multiplicity of infection (MOI) of 100. For adenoviral transduced cells, ZVAD-fmk was added to the cultures to $5 \mu \mathrm{M}$ at day 0 , day 1 , and day 2 , where indicated. Cells were collected for analyses on day 3 after viral transduction.

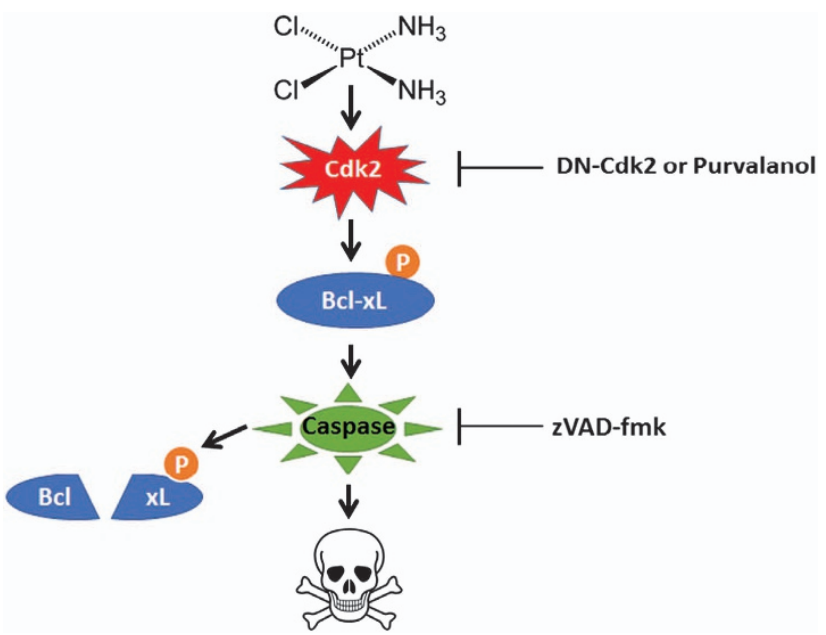

Figure 6. The proposed model of Cdk2 phosphorylation of $\mathrm{BCl}-\mathrm{xL}$ in cisplatin-induced apoptosis. Cdk2 activated in response to cisplatin treatment phosphorylated $\mathrm{Bcl}-\mathrm{xL}$ at Ser73. $\mathrm{Bcl}-\mathrm{xL}$, when phosphorylated at Ser73, promoted self-oligomerization to engage in caspasedependent mitochondrial pathway of apoptosis. ${ }^{11}$ In the process, active capases cleaved $\mathrm{BCl}-\mathrm{xL}$ at previously reported sites, D61 and D76. However, the resulting cleavage products of $\mathrm{BCl}-\mathrm{xL}$ were not necessary for apoptosis. Phosphorylation of Bcl-xL at Ser73 was sufficient to induce cell death. Inhibition of Cdk2 using DN-Cdk2 or purvalanol and inhibition of active caspases using zVAD-fmk blocked caspase activation, and subsequent Bcl-xL cleavage.
Cell-cycle analysis

TKPTS cells were trypsinized and collected by centrifugation at $800 \times g$ for $7 \mathrm{~min}$. The cells were processed for propidium iodide (PI) staining as previously described. ${ }^{8}$ Cell-cycle analysis was performed using FACSCalibur for 10000 cells per experiment, and analyzed by FlowJo (Ashland, OR, USA). Percent apoptosis was quantified by the cell population in sub G0/G1 region ${ }^{31}$ using at least three independent experiments.

\section{Western blot}

Cells were lysed in RIPA lysis buffer $(150 \mathrm{mM} \mathrm{NaCl}, 50 \mathrm{mM}$ Tris $\mathrm{HCl}$ pH 7.5, $0.1 \%$ SDS, $1 \%$ NP-40, $0.5 \%$ sodium deoxycholate, and $1 \mathrm{mM}$ EDTA) supplemented with protease inhibitor cocktail (P8340, Sigma-Aldrich, St Louis, MO, USA). Lysates were sonicated, and centrifuged at 13000 r.p.m. for $10 \mathrm{~min}$ to remove cell debris. Protein concentrations were determined by Bradford assay using Bio-Rad Protein Assay Dye Reagent Concentrate (500-0006, Bio-Rad, Hercules, CA, USA). Equal amount of samples was separated on SDS-PAGE, transferred onto $0.2 \mu \mathrm{m}$ nitrocellulose membrane (162-0097, Bio-Rad), and probed with primary antibody against the protein of interest overnight at $4{ }^{\circ} \mathrm{C}$. Then, the membrane was incubated with appropriate HRP-conjugated secondary antibody. The presence of the protein of interest was detected by Clarity Western ECL Substrate (170-5061, Bio-Rad), and visualized by enhanced chemiluminescence film (28906837, GE Healthcare, Pittsburgh, PA, USA). Primary antibodies used in this study were human/mouse Bcl-x polyclonal antibody (AF800, R\&D Systems, Minneapolis, MN, USA), caspase 3 (9662, Cell Signaling, Danvers, MA, USA), cleaved caspase 3 (9661, Cell Signaling), Cdk2 (ab7954, Abcam, Cambridge, MA, USA), a-tubulin (3873, Cell Signaling), $\beta$-actin (4970, Cell Signaling), Tom20 (sc-11415, Santa Cruz Biotechnology, Santa Cruz, CA, USA), and cytochrome c oxidase subunit IV (4844, Cell Signaling). HRP-linked anti-rabbit IgG (NA934V, GE Healthcare), and HRP-linked antimouse IgG (NXA931, GE Healthcare) were used as the secondary antibodies in this study.

\section{Histone kinase assay}

Untransduced TKPTS cells and TKTPS cells either transduced with $100 \mathrm{MOI}$ DN-Cdk2 adenovirus for $24 \mathrm{~h}$ or treated with $9 \mu \mathrm{M}$ purvalanol for $1 \mathrm{~h}$ were lysed in NP-40 lysis buffer (150 mM NaCl, 50 mM Tris pH 7.5, 1\% NP-40 and $0.5 \mathrm{mM}$ EDTA) supplemented with protease inhibitor cocktail. In vitro kinase assay was performed using histone $\mathrm{H} 1$ (Upstate Biotechnology, Billerica, MA, USA) as a Cdk2 substrate as previously described. ${ }^{32}$

Subcellular fractionation

Cells were harvested using CHAPS lysis buffer (50 mM HEPES, pH 7.4, 5 mM CHAPS, and $5 \mathrm{mM}$ DTT) supplemented with protease inhibitor cocktail. Cell lysate was homogenized by douncing and centrifuged at $16000 \times g$ to separate membranes from supernatant. To analyze membrane-associated proteins, the membrane fraction was further sonicated in RIPA lysis buffer, supplemented with protease inhibitor cocktail.

Site-directed mutagenesis

Site-directed mutagenesis was performed by using the Q5-Site-directed mutagenesis kit (E0554S, New England Biolabs, Ipswich, MA, USA) according to the manufacturer's protocol. D61A mutagenesis was generated by using the forward and reverse primers 5 'GCACCTGGCGGCTA GCCCGGCCG3' and 5'CAGGATGGGTTGCCATTGATGGCACTGG3', respectively. D76A mutation was generated by the forward and reverse primers, 5'CAGCAGTTGGCTGCGCGGGAGG3' and 5'CTGTGGCCAGTGGCTCCATTC3', respectively. To create D61A, D76A double mutation, D61A mutation was created after D76A mutation was performed in S73D-Bcl-xL plasmid. All mutations were confirmed by DNA sequencing, performed at the University of Arkansas for Medical Sciences core facility.

\section{Fluorescent microscopy}

TKPTS cells transduced for $48 \mathrm{~h}$ with WT-Bcl-xL, S73D-Bcl-xL, and ADA-BCl-xL were labeled with $100 \mathrm{nM}$ Mitotracker Red CMXRos (Molecular Probes, Eugene, OR, USA) for $1 \mathrm{~h}$ at $37^{\circ} \mathrm{C}$, fixed, and then processed as previously described. ${ }^{11}$ DAPI-containing mounting media (Vector, Burlingame, CA, USA, $\mathrm{H} 1500)$ was used to label nuclei. Images were acquired using Nikon Eclipse Ti-S (Nikon, Melville, NY, USA), apochromatic $\times 60$ oil lens and NIS Elements imaging software (Nikon). 


\section{Adenovirus}

Adenoviruses for WT-BCl-xL, S73D-BCl-xL, and DN-Cdk2 used in this study were generated as described. ${ }^{10,11,33}$ Using a similar strategy, ADA-BCl-xL adenovirus was generated for this study. In brief, site-directed mutagenesis was performed to generate D61A and D76A in the S73D-BCl-xL plasmid as described above. The cDNA fragment containing the triple mutation (D61A, S73D, and D76A) was excised from the plasmid using restriction enzymes HindIII and EcoRI to replace a similar fragment in pAd-Track-CMVWT-BCl-xL. ADA-BCl-xL adenovirus was generated in AD-293 cells, amplified in HEK-293 cells, and purified using $\mathrm{CsCl}$ banding as described. ${ }^{34}$

\section{Statistical analysis}

All quantitative measures were expressed in mean \pm S.E.M. Probabilities of statistical significance were determined using the two-tailed $t$-test for independent variables with data from at least three separate experiments. Statistical significance was defined as $P<0.05$.

\section{ABBREVIATIONS}

Cdk2, Cyclin-dependent kinase 2; DAPI, 4',6-diamidino-2-phenylindole; DN, dominant-negative; TKPTS, mouse kidney proximal tubule epithelial cells.

\section{ACKNOWLEDGEMENTS}

This work was supported by National Institute of Diabetes and Digestive and Kidney Disease, R01-DK-054471 (to PMP) and a Veterans' Affair Merit Review (to PMP). Experiments were performed with resources and facilities in John L McClellan Memorial Veterans' Hospital in Little Rock, AR, USA.

\section{COMPETING INTERESTS}

The authors declare no conflict of interest.

\section{REFERENCES}

1 Dasari S, Tchounwou PB. Cisplatin in cancer therapy: molecular mechanisms of action. Eur J Pharmacol 2014; 740: 364-378.

2 Pabla N, Dong Z. Cisplatin nephrotoxicity: mechanisms and renoprotective strategies. Kidney Int 2008; 73: 994-1007.

3 Anderson JA, Lewellyn AL, Maller JL. lonizing radiation induces apoptosis and elevates cyclin A1-Cdk2 activity before but not after the midblastula transition in Xenopus. Mol Biol Cell 1997; 8: 1195-1206.

4 Hakem A, Sasaki T, Kozieradzki I, Penninger JM. The cyclin-dependent kinase Cdk2 regulates thymocyte apoptosis. J Exp Med 1999; 189: 957-968.

5 Hiromura K, Pippin JW, Fero ML, Roberts JM, Shankland SJ. Modulation of apoptosis by the cyclin-dependent kinase inhibitor p27(Kip1). J Clin Invest 1999; 103: 597-604.

6 Adachi S, Ito H, Tamamori-Adachi M, Ono Y, Nozato T, Abe S et al. Cyclin A/cdk2 activation is involved in hypoxia-induced apoptosis in cardiomyocytes. Circ Res 2001; 88: 408-414.

7 Hiromura K, Pippin JW, Blonski MJ, Roberts JM, Shankland SJ. The subcellular localization of cyclin dependent kinase 2 determines the fate of mesangial cells: role in apoptosis and proliferation. Oncogene 2002; 21: 1750-1758.

8 Price PM, Safirstein RL, Megyesi J. Protection of renal cells from cisplatin toxicity by cell cycle inhibitors. Am J Physiol Renal Physiol 2004; 286: F378-F384.

9 Price PM, Safirstein RL, Megyesi J. The cell cycle and acute kidney injury. Kidney Int 2009; 76: 604-613.

10 Price PM, Yu F, Kaldis P, Aleem E, Nowak G, Safirstein RL et al. Dependence of cisplatin-induced cell death in vitro and in vivo on cyclin-dependent kinase 2. J Am Soc Nephrol 2006; 17: 2434-2442.

11 Megyesi J, Tarcsafalvi AT, Hti Lar Seng NS, Hodeify R, Price PM. Cdk2 phosphorylation of $\mathrm{Bcl}-\mathrm{xL}$ after stress converts it to a proapoptotic protein mimicking Bax/Bak. Cell Death Discovery 2016; 1: 15066.

12 Billen LP, Kokoski CL, Lovell JF, Leber B, Andrews DW. Bcl-XL inhibits membrane permeabilization by competing with Bax. PLoS Biol 2008; 6: e147.

13 Shamas-Din A, Kale J, Leber B, Andrews DW. Mechanisms of action of Bcl-2 family proteins. Cold Spring Harb Perspect Biol 2013; 5: a008714.
14 Subburaj Y, Cosentino K, Axmann M, Pedrueza-Villalmanzo E, Hermann E, Bleicken S et al. Bax monomers form dimer units in the membrane that further self-assemble into multiple oligomeric species. Nat Commun 2015; 6: 8042.

15 Clem RJ, Cheng EH, Karp CL, Kirsch DG, Ueno K, Takahashi A et al. Modulation of cell death by Bcl-XL through caspase interaction. Proc Natl Acad Sci USA 1998; 95: 554-559.

16 Fujita N, Nagahashi A, Nagashima K, Rokudai S, Tsuruo T. Acceleration of apoptotic cell death after the cleavage of $\mathrm{Bcl}-\mathrm{XL}$ protein by caspase-3-like proteases. Oncogene 1998; 17: 1295-1304.

17 Basanez G, Zhang J, Chau BN, Maksaev Gl, Frolov VA, Brandt TA et al. Pro-apoptotic cleavage products of $\mathrm{Bcl}-\mathrm{xL}$ form cytochrome c-conducting pores in pure lipid membranes. J Biol Chem 2001; 276: 31083-31091.

18 Ofengeim D, Chen YB, Miyawaki T, Li H, Sacchetti S, Flannery RJ et al. N-terminally cleaved Bcl-xL mediates ischemia-induced neuronal death. Nat Neurosci 2012; 15: 574-580.

19 Muchmore SW, Sattler M, Liang H, Meadows RP, Harlan JE, Yoon HS et al. $\mathrm{X}$-ray and NMR structure of human Bcl-XL, an inhibitior of programmed cell death. Nature 1996; 381: 335-341.

20 Chen M, Guerrero AD, Huang L, Shabier Z, Pan M, Tan TH et al. Caspase-9-induced mitochondrial disruption through cleavage of anti-apoptotic $B C L-2$ family members. J Biol Chem 2007; 282: 33888-33895.

21 Desagher S, Martinou JC. Mitochondria as the central control point of apoptosis. Trends Cell Biol 2000; 10: 369-377.

22 Chang BS, Minn AJ, Muchmore SW, Fesik SW, Thompson CB. Identification of a novel regulatory domain in $\mathrm{Bcl}-\mathrm{X}(\mathrm{L})$ and $\mathrm{Bcl}-2$. EMBO $J$ 1997; 16: 968-977.

23 Haldar S, Chintapalli J, Croce CM. Taxol induces bcl-2 phosphorylation and death of prostate cancer cells. Cancer Res 1996; 56: 1253-1255.

24 Upreti M, Galitovskaya EN, Chu R, Tackett AJ, Terrano DT, Granell S et al. Identification of the major phosphorylation site in $\mathrm{Bcl}-\mathrm{xL}$ induced by microtubule inhibitors and analysis of its functional significance. J Biol Chem 2008; 283: 35517-35525.

25 Boise LH, Gonzalez-Garcia M, Postema CE, Ding L, Lindsten T, Turka LA et al. $\mathrm{Bcl}-\mathrm{x}$, a bcl-2-related gene that functions as a dominant regulator of apoptotic cell death. Cell 1993; 74: 597-608.

26 Thomas WD, Zhang XD, Franco AV, Nguyen T, Hersey P. TNF-related apoptosisinducing ligand-induced apoptosis of melanoma is associated with changes in mitochondrial membrane potential and perinuclear clustering of mitochondria. J Immunol 2000; 165: 5612-5620.

$27 \mathrm{Li} \mathrm{H}$, Zhu H, Xu CJ, Yuan J. Cleavage of BID by caspase 8 mediates the mitochondrial damage in the Fas pathway of apoptosis. Cell 1998; 94: 491-501.

28 Dewitt DA, Hurd JA, Fox N, Townsend BE, Griffioen KJ, Ghribi O et al. Peri-nuclear clustering of mitochondria is triggered during aluminum maltolate induced apoptosis. J Alzheimers Dis 2006; 9: 195-205.

29 Miller RP, Tadagavadi RK, Ramesh G, Reeves WB. Mechanisms of cisplatin nephrotoxicity. Toxins 2010; 2: 2490-2518.

30 Ernest S, Bello-Reuss E. Expression and function of P-glycoprotein in a mouse kidney cell line. Am J Physiol Cell Physiol 1995; 269: C323-C333.

31 Riccardi C, Nicoletti I. Analysis of apoptosis by propidium iodide staining and flow cytometry. Nat Protoc 2006; 1: 1458-1461.

32 Hodeify R, Tarcsafalvi A, Megyesi J, Safirstein RL, Price PM. Cdk2-dependent phosphorylation of p21 regulates the role of $\mathrm{Cdk} 2$ in cisplatin cytotoxicity. Am J Physiol Renal Physiol 2011; 300: F1171-F1179.

33 Luo J, Deng ZL, Luo X, Tang N, Song WX, Chen J et al. A protocol for rapid generation of recombinant adenoviruses using the AdEasy system. Nat Protoc 2007; 2: 1236-1247.

34 Hodeify R, Megyesi J, Tarcsafalvi A, Safirstein RL, Price PM. Protection of cisplatin cytotoxicity by an inactive cyclin-dependent kinase. Am J Physiol Renal Physiol 2010; 299: F112-F120.

This work is licensed under a Creative Commons Attribution 4.0 International License. The images or other third party material in this article are included in the article's Creative Commons license, unless indicated otherwise in the credit line; if the material is not included under the Creative Commons license, users will need to obtain permission from the license holder to reproduce the material. To view a copy of this license, visit http://creativecommons.org/licenses/ by/4.0/ 